\title{
ELEMENTS OF URBAN ECOLOGY: WATER QUALITY ASSESSMENT OF THE LAKES BUILD UP ON COLENTINA RIVER IN BUCHAREST AREA
}

\author{
Bogdan Stanescu, Gheorghe Batrinescu, Adriana Cuciureanu, Lidia Kim, \\ Elena Stanescu
}

National Research and Development Institute for Industrial Ecology, Bucharest, 71-73 Drumul Podul Dambovitei street, district 6, zip code 060652, evmt@incdecoind.ro, Romania

\begin{abstract}
Lakes located in urban areas and near urban agglomerations is an important interface between on the one hand, the geographic areas, and, ecology on the other. This determines to be necessary strategic environmental approaches in urban development and in-depth knowledge of the complex issues of urban lakes, such as: flood behavior, the existence of pollution sources, the water quality status, etc.

This paper aims to highlight aspects of the water pollution of lakes in Bucharest based on build a conceptual model that includes all relevant information related to the anthropogenic lakes on the river Colentina. All this information allowed to delimiting the study area, as well as 11 control points, respectively locations for sampling and subsequently laboratory analysis of a set of the specific quality indicators for assessing surface water quality. The location of the samples was recorded via GPS, resulting a georeferenced database populated with data that highlight a number of issues related to pollution in urban areas.

The main conclusions reveal the existence of the differences both spatial and temporal of the quality status of the lake system analyzed, which are due to the manifestation of a series of the specific factors: local sources of the pollution, the contribution of the rainfall, seasonal changes in water volume throughput lakes etc. The pollution is recorded easily in the sediment accumulation, given that there have been not achieved over time specific maintenance works, such as dredging for lakes in Bucharest.
\end{abstract}

Keywords: hydrology, urban lakes, water quality

\section{Introduction}

Since 1936 was started construction of the lakes on the river Colentina drawn as a chain cascade[1]. They started from necessity for draining marshy river bed of Colentina. Dams are the type of homogeneous soil dam with upstream pereat with concrete slabs and the downstream covered with grass. Long service lakes caused them to store large amounts of silt that have not been dredged for maintenance project construction parameters. So there are a number of malfunctions in exploiting these lakes that lie in the lower lakes depth or decrease retention capacity, and changes in temperature regime with implications for regime changes as algal blooms and oxygen regime in hot summer periods. There have been numerous reported cases of mortality of the fishs, and unpleasant odors in some areas of recreation capital. There are numerous studies that reinforce the necessity to know lake ecosystems areas with multiple functionalities: economic, travel, recreation etc. [2]

The anthropic lakes along the watercourse of the Colentina river is distinguished as a special category compared with natural or semi-open closed system, such as lakes in coastal areas [3].The elements of the conceptual 
framework were identified based on informations from the literature or similar studies on urban lakes areas [4], are integrated and presented in Figure 1. Current and relevant information were made and by the direct observations obtained by visiting the site of the study area.

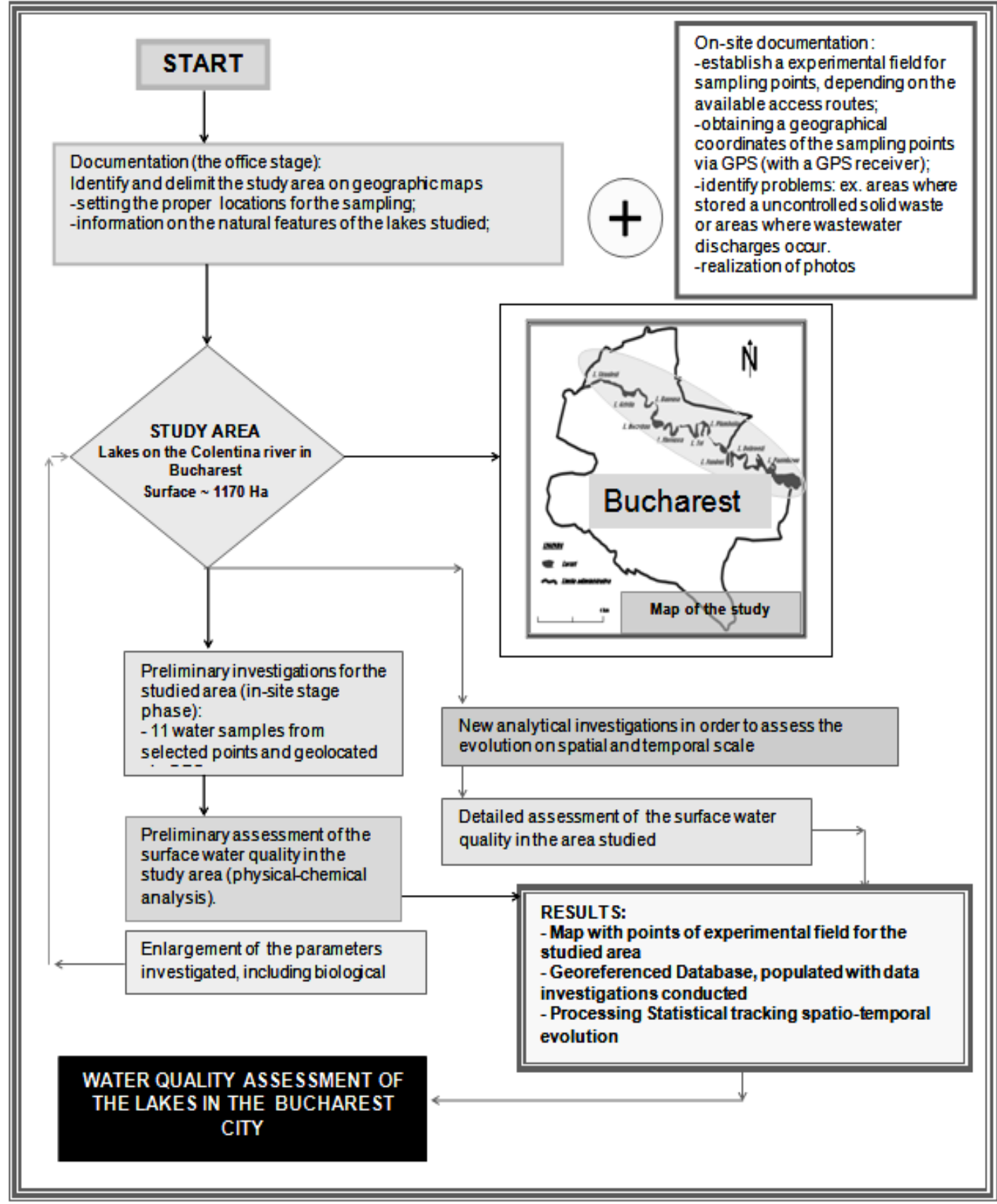

Fig 1. Conceptual model for the study area

\section{Experimental}

It was conducted a experimental field consists of 11 sampling points for surface water shown in Figure 2, start from Mogosoaia Lake in upstream section up to Cernica lake in downstream of the Bucharest city limits. The surface water sampling was conducted in September and November 2014; were used telescopic scooper sampler equipment and all samples were preserved and 
transported in proper conditions to laboratory [5-6]. Water samples taken were analyzed in the laboratory were applied standardized test methods (Table 1), using advanced analytical equipment and the modern technology.

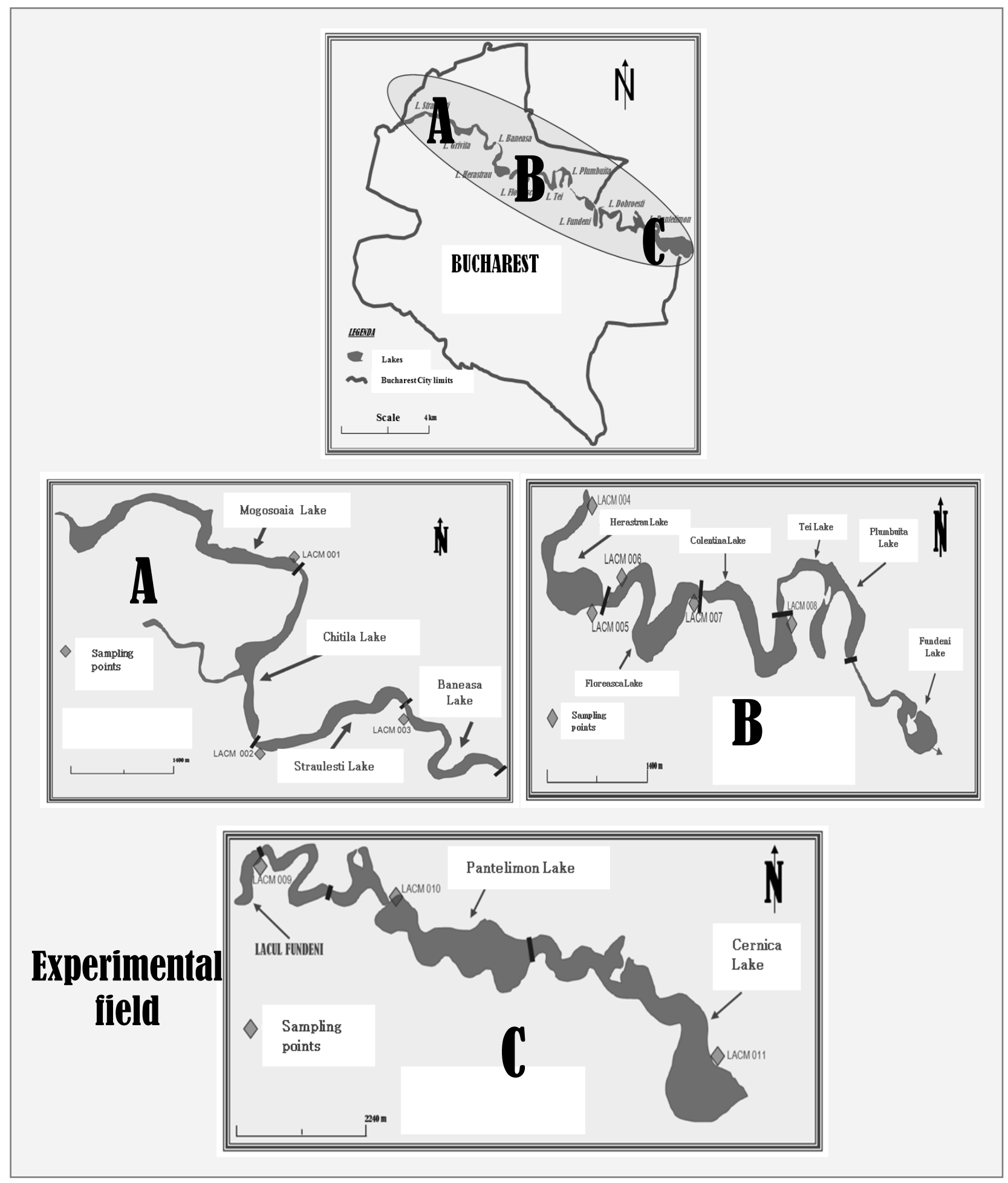

Fig 2. Experimental field for the study area 
Table 1 - Quality indicators and test methods

\begin{tabular}{|c|c|c|}
\hline No. & Quality indicators & Test methods \\
\hline 1 & $\mathrm{pH}$ & SR EN ISO 10523:2012 \\
\hline 2 & temperature & SR EN 27888-97 \\
\hline 3 & conductivity & SR ISO 7150/1-01 \\
\hline 4 & ammonium & SR ISO 7890/3:2000 \\
\hline 5 & nitrates & SR EN 26777:2002/C91:2006 \\
\hline 6 & nitrites & SR EN 12260:2004 \\
\hline 7 & total nitrogen & STAS 8601-70 \\
\hline 8 & total phosphorus & SR ISO 9297-01 \\
\hline 9 & sulphates & SR EN ISO 17294-2005 \\
\hline 10 & clorides & SR EN ISO 7980-2002 \\
\hline 11 & copper & SR EN ISO 17294-2005 \\
\hline 12 & sodium & SR EN ISO 17294-2005 \\
\hline 13 & iron & SR EN ISO 17294-2005 \\
\hline 14 & zinc & SR EN ISO 17294-2005 \\
\hline 15 & manganese & SR EN ISO 17294-2005 \\
\hline 16 & lead & SR EN ISO 17294-2005 \\
\hline 17 & arsenic & SR EN 1899p1,2:2003-2002 \\
\hline 18 & total chromium & SR ISO 6060-1996 \\
\hline 19 & BOD & SR EN 25813-2000/C91:2009 \\
\hline 20 & organic load (CCOCr) & \\
\hline 21 & dissolved oxygen & \\
\hline
\end{tabular}

\section{Results and Discussion}

The results of the determining the physico-chemical quality indicators are presented in table no. 2, and 3 .

Table no.2 - Results of the investigations for the lakes on the river Colentina (Bucharest and surrounding areas), campaign conducted in September 2014

\begin{tabular}{|c|c|c|c|c|c|c|c|c|c|c|c|}
\hline \multirow{2}{*}{$\begin{array}{l}\text { Quality } \\
\text { indicator / } \\
\text { measure } \\
\text { unit }\end{array}$} & \multicolumn{11}{|c|}{ Sample code } \\
\hline & $\begin{array}{l}\text { LACM } \\
001\end{array}$ & $\begin{array}{l}\text { LACM } \\
002\end{array}$ & $\begin{array}{l}\text { LACM } \\
003\end{array}$ & $\begin{array}{l}\text { LACM } \\
004\end{array}$ & $\begin{array}{l}\text { LACM } \\
005\end{array}$ & $\begin{array}{l}\text { LACM } \\
006\end{array}$ & $\begin{array}{l}\text { LACM } \\
007\end{array}$ & $\begin{array}{l}\text { LACM } \\
008\end{array}$ & $\begin{array}{l}\text { LACM } \\
009\end{array}$ & $\begin{array}{l}\text { LACM } \\
010\end{array}$ & $\begin{array}{c}\text { LACM } \\
011\end{array}$ \\
\hline $\mathrm{pH}$ (unit $\mathrm{pH})$ & 7,16 & 7,22 & 6,54 & 6,51 & 6,37 & 6,58 & 6,48 & 6,55 & 7,41 & 6,58 & 6,37 \\
\hline Temp. $\left({ }^{\circ} \mathrm{C}\right)$ & 18,2 & 18,6 & 18,8 & 19,0 & 18,3 & 19,2 & 18,5 & 18,6 & 18,2 & 19,1 & 18,6 \\
\hline $\mathrm{O}_{2}\left(\mathrm{mgO}_{2} / \mathrm{l}\right)$ & 3,80 & 2,66 & 4,55 & 4,83 & 2,41 & 4,91 & 4,37 & 3,0 & 5,03 & 4,79 & 4,60 \\
\hline $\begin{array}{l}\text { Cond. } \\
\text { ( } \mu \mathrm{s} / \mathrm{cm})\end{array}$ & 380 & 389 & 402 & 403 & 404 & 411 & 405 & 419 & 456 & 412 & 413 \\
\hline $\mathrm{BOD}\left(\mathrm{mgO}_{2} / \mathrm{l}\right)$ & 21 & 3,1 & 5,9 & 4,8 & 1,2 & 2,3 & 3,2 & 11,8 & 3,1 & 1,4 & 4,1 \\
\hline $\begin{array}{l}\text { Organic load } \\
\mathrm{CCOCr} \\
\left(\mathrm{mgO}_{2} / \mathrm{l}\right)\end{array}$ & 67,2 & $\begin{array}{l}<30^{*} \\
(9,6)\end{array}$ & $\begin{array}{c}<30^{*} \\
(17,6)\end{array}$ & $\begin{array}{l}<30^{*} \\
(14,4)\end{array}$ & $\begin{array}{l}<30^{*} \\
(4,8)\end{array}$ & $\begin{array}{l}<30^{*} \\
(8,8)\end{array}$ & $\begin{array}{l}<30^{*} \\
(9,6)\end{array}$ & 38,40 & $\begin{array}{l}<30^{*} \\
(9,6)\end{array}$ & $\begin{array}{l}<30^{*} \\
(4,8)\end{array}$ & $\begin{array}{l}<30^{*} \\
(14,4)\end{array}$ \\
\hline $\begin{array}{l}\text { Ammonium } \\
(\mathrm{mgN} / \mathrm{l})\end{array}$ & 0,422 & 0,392 & 0,644 & 0,444 & 0,934 & 0,460 & 0,556 & 0,636 & 0,350 & 0,592 & 0,470 \\
\hline $\begin{array}{l}\text { Nitrates } \\
(\mathrm{mgN} / \mathrm{l})\end{array}$ & 2,08 & 2,25 & 1,62 & 1,16 & 2,11 & 1,61 & 1,09 & 1,61 & 2,96 & 1,65 & 2,25 \\
\hline $\begin{array}{l}\text { Nitrites } \\
(\mathrm{mgN} / \mathrm{l})\end{array}$ & 0,113 & 0,072 & $=0,002^{*}$ & $=0,002^{*}$ & $=0,002^{*}$ & $=0,002^{*}$ & $=0,002^{*}$ & $=0,002^{*}$ & 0,053 & 0,040 & 0,051 \\
\hline $\begin{array}{l}\text { Total } \\
\text { Nitrogen } \\
\text { (mgN/l) }\end{array}$ & 1,14 & 1,02 & 1,20 & 0,98 & 1,96 & 1,16 & 0,92 & 1,18 & 1,71 & 1,02 & 1,21 \\
\hline
\end{tabular}


Table no.2 - continuation

\begin{tabular}{|c|c|c|c|c|c|c|c|c|c|c|c|}
\hline $\begin{array}{l}\text { Total } \\
\text { phosphorus } \\
(\mathrm{mgP} / \mathrm{l})\end{array}$ & 0,285 & 0,146 & 0,092 & 0,078 & 0,188 & 0,081 & 0,079 & 0,065 & 0,053 & 0,068 & 0,075 \\
\hline $\begin{array}{l}\text { Clorides } \\
\text { (mg/l) }\end{array}$ & 16,50 & 33 & 29,71 & 33,01 & 33 & 39,61 & 33,01 & 36,31 & 41,26 & 39,61 & 36,31 \\
\hline $\begin{array}{l}\text { Sulphates } \\
(\mathrm{mg} / \mathrm{l})\end{array}$ & 76,95 & 46,91 & 86 & 78,59 & 56,78 & 61,31 & $\begin{array}{c}107,8 \\
1\end{array}$ & 98,76 & 83,94 & 201 & $\begin{array}{c}111,1 \\
0\end{array}$ \\
\hline $\begin{array}{l}\text { Sodium } \\
\text { (mg/l) }\end{array}$ & 9,83 & 8,71 & 10,60 & 15,50 & 11,20 & 8,56 & 19,36 & 12,40 & 17,20 & 15,80 & 19,48 \\
\hline $\operatorname{Iron}(\mathrm{mg} / \mathrm{l})$ & 0,011 & $=0,003^{*}$ & 0,013 & $=0,003^{*}$ & 0,018 & 0,009 & 0,01 & 0,008 & $=0,003^{*}$ & 0,007 & 0,012 \\
\hline $\begin{array}{l}\text { Copper } \\
(\mathrm{mg} / \mathrm{l})\end{array}$ & 0,018 & 0,012 & 0,014 & 0,012 & 0,006 & 0,01 & 0,009 & 0,007 & 0,011 & 0,012 & 0,013 \\
\hline Zinc (mg/l) & 0,015 & 0,01 & 0,016 & 0,008 & 0,015 & 0,007 & 0,011 & 0,008 & 0,018 & 0,006 & 0,005 \\
\hline $\begin{array}{l}\text { Manganese } \\
(\mathrm{mg} / \mathrm{l})\end{array}$ & 0,047 & 0,035 & 0,024 & 0,046 & 0,014 & 0,048 & 0,046 & 0,022 & 0,038 & 0,018 & 0,036 \\
\hline Lead (mg/l) & $<0,01^{*}$ & $<0,01^{*}$ & $<0,01^{*}$ & $<0,01^{*}$ & $<0,01^{*}$ & $<0,01^{*}$ & $<0,01^{*}$ & $<0,01^{*}$ & $<0,01^{*}$ & $<0,01^{*}$ & $<0,01^{*}$ \\
\hline $\operatorname{Arsen}(\mathrm{mg} / \mathrm{l})$ & $<0,003^{*}$ & $=0,003^{*}$ & $0,003^{*}$ & $=0,003^{*}$ & $0,003^{*}$ & $0,003^{*}$ & $=0,003^{*}$ & $=0,003^{*}$ & $=0,003^{*}$ & $=0,003^{*}$ & $=0,003^{*}$ \\
\hline $\begin{array}{l}\text { Total } \\
\text { chromium } \\
\text { (mg/l) }\end{array}$ & 0,014 & 0,011 & 0,013 & 0,035 & 0,017 & 0,011 & 0,014 & 0,008 & 0,009 & 0,012 & 0,011 \\
\hline
\end{tabular}

Tabel no.3 - Results of the investigations for the lakes on the river Colentina (Bucharest and surrounding areas), campaign conducted in November 2014

\begin{tabular}{|c|c|c|c|c|c|c|c|c|c|c|c|}
\hline \multirow{2}{*}{$\begin{array}{l}\text { Quality } \\
\text { indicator / } \\
\text { measure } \\
\text { unit }\end{array}$} & \multicolumn{11}{|c|}{ Sample code } \\
\hline & $\begin{array}{c}\text { LAC } \\
M \\
001\end{array}$ & $\begin{array}{c}\text { LAC } \\
M \\
002\end{array}$ & $\begin{array}{c}\text { LAC } \\
M \\
003\end{array}$ & $\begin{array}{c}\text { LAC } \\
M \\
004\end{array}$ & $\begin{array}{c}\text { LAC } \\
M \\
005\end{array}$ & $\begin{array}{c}\text { LAC } \\
\text { M } \\
006\end{array}$ & $\begin{array}{c}\text { LAC } \\
M \\
007\end{array}$ & $\begin{array}{c}\text { LAC } \\
M \\
008\end{array}$ & $\begin{array}{c}\text { LAC } \\
M \\
009\end{array}$ & $\begin{array}{c}\text { LAC } \\
M \\
010\end{array}$ & $\begin{array}{c}\text { LAC } \\
\text { M } \\
011\end{array}$ \\
\hline $\mathrm{pH}$ (unit $\mathrm{pH}$ ) & 6,06 & 5,94 & 7,16 & 6,35 & 6,28 & 7,20 & 6,88 & 5,82 & 6,01 & 6,88 & 6,10 \\
\hline Temp. $\left({ }^{0} \mathrm{C}\right)$ & 19,6 & 19,6 & 19,8 & 19,6 & 19,8 & 19,8 & 19,6 & 19,7 & 19,8 & 19,6 & 19,8 \\
\hline $\mathrm{O}_{2}\left(\mathrm{mgO}_{2} / \mathrm{l}\right)$ & 5,12 & 5,10 & 5,27 & 4,89 & 5,31 & 5,20 & 5,72 & 5,60 & 5,29 & 4,71 & 5,50 \\
\hline $\begin{array}{l}\text { Cond. } \\
(\mu \mathrm{s} / \mathrm{cm})\end{array}$ & 392 & 392 & 409 & 422 & 428 & 436 & 429 & 446 & 495 & 775 & 477 \\
\hline $\mathrm{BOD}\left(\mathrm{mgO}_{2} / \mathrm{l}\right)$ & 24 & 4,8 & 29,4 & 27 & 3,4 & 2,9 & 3,4 & 48 & 4,1 & 31 & 3,8 \\
\hline $\begin{array}{l}\text { Organic load } \\
\mathrm{CCOCr} \\
\left(\mathrm{mgO}_{2} / \mathrm{l}\right)\end{array}$ & 76,8 & $\begin{array}{l}<30^{*} \\
(14)\end{array}$ & 96 & 86,4 & $\begin{array}{l}<30^{*} \\
(10,8)\end{array}$ & $\begin{array}{l}<30^{*} \\
(9,2)\end{array}$ & $\begin{array}{l}<30^{*} \\
(11)\end{array}$ & 144 & $\begin{array}{l}<30^{*} \\
(12)\end{array}$ & 96 & $\begin{array}{l}<30^{*} \\
(11,6)\end{array}$ \\
\hline $\begin{array}{l}\text { Ammonium } \\
(\mathrm{mgN} / \mathrm{l})\end{array}$ & 0,312 & 0,272 & 0,312 & 0,294 & 0,234 & 0,284 & 0,558 & 0,508 & 0,556 & 0,694 & 0,474 \\
\hline & 3,59 & 3,49 & 4,75 & 4,53 & 4,05 & 3,05 & 4,12 & 3,92 & 4,68 & 13,02 & 4,77 \\
\hline $\begin{array}{l}\text { Nitrites } \\
(\mathrm{mgN} / \mathrm{l})\end{array}$ & 0,085 & 0,075 & 0,123 & 0,123 & 0,109 & 0,115 & 0,107 & 0,088 & 0,123 & 0,780 & 0,132 \\
\hline $\begin{array}{l}\text { Total } \\
\text { Nitrogen } \\
(\mathrm{mgN} / \mathrm{l})\end{array}$ & 1,65 & 1,22 & 1,82 & 1,56 & 1,35 & 1,21 & 1,67 & 1,80 & 1,76 & 4,08 & 1,66 \\
\hline $\begin{array}{l}\text { Total } \\
\text { phosphorus } \\
(\mathrm{mgP} / \mathrm{l})\end{array}$ & 0,103 & 0,031 & 0,046 & 0,031 & 0,035 & 0,030 & 0,028 & 0,023 & 0,027 & 0,040 & 0,024 \\
\hline $\begin{array}{l}\text { Clorides } \\
\text { (mg/l) }\end{array}$ & 19,52 & 21,30 & 26,62 & 28,40 & 35,50 & 33,72 & 31,95 & 35 & 42,60 & 88,75 & 17,75 \\
\hline $\begin{array}{l}\text { Sulphates } \\
\text { (mg/l) }\end{array}$ & 55,96 & 46 & 55,96 & 51,43 & 47,73 & 57,20 & 44,03 & 48,55 & 55,14 & 31,27 & 58,84 \\
\hline $\begin{array}{l}\text { Sodium } \\
(\mathrm{mg} / \mathrm{l})\end{array}$ & 10,56 & 7,83 & 8,72 & 11,21 & 10,82 & 6,86 & 13,84 & 9,43 & 12,18 & 9,91 & 23,44 \\
\hline Iron (mg/l) & 0,021 & 0,011 & 0,017 & $<0,003^{*}$ & 0,009 & 0,012 & 0,007 & $<0,003^{*}$ & 0,007 & 0,011 & 0,019 \\
\hline $\begin{array}{l}\text { Copper } \\
(\mathrm{mg} / \mathrm{l})\end{array}$ & 0,013 & 0,015 & 0,008 & 0,009 & 0,009 & 0,019 & 0,012 & 0,005 & 0,015 & 0,015 & 0,022 \\
\hline
\end{tabular}




\section{Tabel no.3-continuation}

\begin{tabular}{|l|c|c|c|c|c|c|c|c|c|c|c|}
\hline Zinc (mg/l) & 0,012 & 0,006 & 0,028 & 0,011 & 0,011 & 0,013 & 0,009 & 0,007 & 0,031 & 0,025 & 0,013 \\
\hline $\begin{array}{l}\text { Manganese } \\
\text { (mg/l) }\end{array}$ & 0,056 & 0,021 & 0,035 & 0,029 & 0,018 & 0,035 & 0,015 & 0,012 & 0,045 & 0,031 & 0,056 \\
\hline Lead (mg/l) & 0,05 & 0,03 & $<0,01^{*}$ & $<0,01^{*}$ & $<0,01^{*}$ & $0,011^{*}$ & $<0,01^{*}$ & $<0,01^{*}$ & $<0,01^{*}$ & 0,011 & $<0,01^{*}$ \\
\hline Arsen(mg/l) & $<0,01^{*}$ & $<0,01^{*}$ & $<0,01^{*}$ & $<0,01^{*}$ & $<0,01^{*}$ & $<0,01^{*}$ & $<0,01^{*}$ & $<0,01^{*}$ & $<0,01^{*}$ & 0,011 & $<0,01^{*}$ \\
\hline $\begin{array}{l}\text { Total } \\
\text { chromium } \\
\text { (mg/l) }\end{array}$ & 0,017 & 0,009 & 0,021 & 0,019 & 0,009 & 0,016 & 0,008 & 0,009 & 0,012 & 0,009 & 0,019 \\
\hline
\end{tabular}

*detection limit of the test method

The results obtained from investigations performed in September and October 2014 in correlation with other relevant informations to the study of urban lake areas were highlighted as follows:

- the maximum daytime temperature was between $21^{\circ} \mathrm{C}$ and $18^{\circ} \mathrm{C}$ in September to the end of the month, and in the first decade of November; the maximum nightly temperatures between $4^{\circ} \mathrm{C}$ to $2^{\circ} \mathrm{C}$ in the end days of September and the first decade of November;

- was recorded a regime of the hydrogen ion concentrations below permissible limits in November, the month when most lakes on the river Colentina chain showed a low water volume due to the draw made in this time of the year;

- the values of the oxygen regime induce a "weak" or "bad" ecological situations, this aspect is recorded in September 2014; the biochemical oxygen demand (BOD) shows significant variations from one area to another from "good" ecological status to "bad" to a sharp deterioration in November in conditions of low levels in lakes. Among of the areas with a pronounced degradation can be mentionMogosoaia, Baneasa in the proximity of the lake Grivita and Pantelimon lake.

- the nutrient regime:

- „ammonium” content reveals higher values in September compared to November and the worst overall values induce moderate ecological state;

- The values recorded of the "nitrates" content in November are much higher than those in September, an exceptional value was recorded in samples taken from Lake Pantelimon in November, inducing a „poor” ecological state;

- "nitrogen" content reveals a "good" and "moderate” ecological status in most of the lakes also analyzed with higher values in November compared with September; remains the same except of the Pantelimon Lake with a "bad" ecological state;

- "total phosphorus content” present higher values in September compared to November, most of the values induce a "good" ecological status. 


\section{Conclusions}

The analytical results obtained were correlated with a series of the preliminary data obtained in March 2014 and the results of the hydrobiological analysis of surface water in the study area. Also taken into account the relevant informations collected in-situ in order to elucidate important issues relate to the quality of the lake surface waters in Bucharest. They mentioned a number of the conclusions to be supplemented, as it will add new data which will be obtained in further investigations:

* There identify a series of the anthropogenic pressures on areas most important lakes of which would be: an uncontrolled disposal of waste on the lakes, importing some of them end up in lakes, ex. Cernica Lake and Lake Pantelimon

- a point discharges of the domestic wastewater in lakes;

- a rain water discharges, potentially contaminated: a important cantities of the waters that washes concrete surfaces / asphalt from Bucharest (ex. bridge evacuations in areas Straulesti, Floreasca Pantelimon etc);

- a large quantity of the silt stored in lakes along the long periods of the operation;

- Reveals a moderate effect on physico-chemical quality indicators analyzed, mostly identified in sections downstream, practical urban influence is felt or negative impact on the status of surface water quality in these lakes.

It is important to know as well the issue of urban lake areas in order to achieve effective management of these areas. One problem identified and so far unsolved large amount of silt is stored in the beds of these lakes that have not been subjected to dredging activities, the silt is a true repository of accumulated contaminants over the time.

\section{Acknowledgements}

Research activities were conducted in the frame of the research program "Core Program", in 2014.

\section{References}

[1] http://www.alpa.ro/

[2] S. Ryanzhin, N. Kochkov, N. Akhmentova, N. Weinmeister, 2011, Costal Lakes of the Black Sea, Journal of Environmental Protection and Ecology, vol.12 No.1, Pages 25-30

[3] I. Malollari, A. Bacu, A.Bekteshi, F. Babani, S. Uku, 2012, Nutrition factors of the Shkodra Lake waters and their distribution, Journal of Environmental Protection and Ecology, vol.13 No.2, Pages 532-540

[4] Kwak, T.J. and M.C. Freeman. 2010. Assessment and management of ecological integrity. Pages 353- 394 in W.A. Hubert and M.C. Quist, editors. Inland fisheries management in North America, third edition. American Fisheries Society, Bethesda, Maryland.

[5] ISO 5667-6 (2009) Water quality. Sampling. Part 6: Guidance on sampling of rivers and streams.

[6] ISO 5667-12 (2001) Water quality. Sampling. Part 12: Guidance on sampling of bottom sediment. 